\title{
РАДІОФІЗИКА ГЕОКОСМОСУ
}

DOI: https://doi.org/10.15407/rpra24.02.129

удк 551.610 .51

PACS numbers: 92.60.Mt, 89.60.-k

\section{A. B. COIHA}

Радіоастрономічний інститут НАН України, вул. Мистецтв, 4, м. Харків, 61002, Україна

E-mail: aditu@rian.kharkov.ua

\section{СЕМИДЕННА ЦИКЛІЧНІСТЬ В ПАРАМЕТРАХ АТМОСФЕРНИХ АЕРОЗОЛІВ ЗА ДАНИМИ СТАНЦІЙ АЕRОNЕТ В УКРАЇНІ}

\begin{abstract}
Предмет і мета роботи: Метою роботи є пошук, аналіз та порівняння тижневої циклічності у поведінці оптичних характеристик атмосферних аерозолів, зокрема аерозольної оптичної товщіі, в регіонах України з різним ступенем техногенного навантаження на довкілля.

Методи і методологія: Для пошуку семиденних варіащій використано дані всесвітньої мережі моніторингу аерозолів AERONET, діяльність якої трунтується на роботі автоматичних уніфікованих сонячних фотометрів Cimel CE-318 (Франиія). Проаналізовано масив річних даних вимірювань аерозольної оптичної товщзі у двох спектральних каналах 440 та 870 нм, (надалі АОТ440 та АОТ870) у 2014 р. Порівнювались дані моніторингу двох украӥнських станцій. Перша розташована у м. Києві, друга - у с. Мартове Печенізького району Харківської області. Оскільки дані сонячного фотометра є дискретними, для їх статистичної обробки було обрано метод накладання епох.

Результати: В результаті виконаних розрахунків параметрів АОТ440 та АОТ870 було визначено наявність семиденних варіацій у ичих параметрах в обох регіонах. 3 метою перевірки подібності “уікенд-ефекту” у варіаціях концентрації аерозолів у атмосфері над м. Києвом та с. Мартове було визначено максимальні значення коефіцієнтів взаємної кореляиії досліджуваних параметрів. Встановлено, щзо коефіцієнт кореляиії для двох рядів середніх значень параметра АОТ440, розрахованих за даними двох станцій, становить близько 0.7, а для АОТ870 - сягає 0.9. Такі результати дозволяють стверджувати, щзо прояви “уікенд-ефекту” у варіаціях концентрації аерозолів як над екологічно чистою територією (с. Мартове), так і над індустріально розвинутим м. Києвом є практично ідентичні.

Висновки: Встановлено наявність семиденних варіацій в параметрах атмосферних аерозолів АОТ440 та АOT870 в обох пунктах спостереження в Україні, максимальні значення параметрів реєструються у п'ятницю. Аналіз показав високий ступінь кореляиії результатів спостережень на двох станціях. Враховуючі різний ступінь антропогенного навантаження на урбанізований район та рекреаційну зону України, в яких розташовані станиії, та високу подібність семиденних ииклів параметрів АОТ440 та АОТ870, зареєстрованих у 2014 р., можна стверджувати, щуо висновки попередніх досліджень щзодо суттєвості і глобальності впливу людини на довкілля підтвердилися.
\end{abstract}

Ключові слова: аерозольна оптична товщза (АОТ), аерозолі, “уікенд-ефект”, атмосфера, взаємна кореляція, антропогенний влив

\section{1. Ветуп}

Антропогенна активність стала головною причиною появи семиденного тижневого циклу у поведінці атмосферних параметрів, який не існував до техногенної епохи. Дослідження щодо пошуку варіацій в різноманітних параметрах довкілля (наприклад таких, як вміст парникових газів [1], температура повітря, атмосферний тиск, тощо [2]), пов'язаних з семиденним тижнем, виконувалися багатьма вченими. Раніше в роботі [3] була викладена гіпотеза щодо виникнення тижневої циклічності (“уікенд-ефект”) у глобальній грозовій активності, яку було встановлено за варіаціями потужності наднизькочастотних шумів у діапазоні
$5 \div 25$ Гц, зареєстрованими на Українськиій антарктичній станції Академік Вернадський. Пояснити таку періодичність можна антропогенними викидами твердих частинок аерозолю в атмосферу, які впливають на характеристики хмар i, як наслідок, можуть призводити до змін параметрів грозової активності.

Слід зазначити, що вплив аерозолів на стан нижніх шарів атмосфери вивчається досить давно [4]. Актуальність цих досліджень збільшується у зв'язку зі швидким розвитком промисловості та посиленням індустріального впливу на повітряну оболонку планети. Останнім часом стаціонарні джерела забруднення на планеті викидають по- 
над $10^{8}$ т аерозолів техногенного походження щороку [5]. Їх вплив на атмосферу особливо істотно проявляється у промислово розвинутих, урбанізованих регіонах нашої планети.

Пошуки тижневої циклічності у поведінці аерозолів виконувалися різними дослідниками $[6,7]$, у тому числі й за участю автора даної роботи [8]. Зокрема, була проаналізована поведінка і продемонстрована наявність тижневих варіацій характеристик атмосферних аерозолів у промислово розвинутих регіонах світу - Свропі та Північній Америці. Аерозольна оптична товщина (АОТ), як показник техногенного впливу, є чутливим індикатором стану довкілля. Українські вчені досліджували аерозольні властивості на територіях як нашої країни, так і сусідніх держав $[9,10]$. Завдяки існуванню глобальної мережі моніторингу аерозолів AERONET (http://aeronet. gsfc.nasa.gov) та доступу, у відповідності до вимог сайту AERONET, до баз даних вимірювань можливо здійснювати пошук тижневої періодичності параметрів АОТ майже в усіх регіонах земної кулі. Сьогодні ця мережа об'єднує понад 500 станцій спостережень, дві з яких розташовано в Україні - станція Київ 3 географічними координатами $50.364^{\circ}$ пн. ш., $30.497^{\circ}$ сх. д. (функціонує з 2007 р.) та станція Мартова, з географічними координатами $49.936^{\circ}$ пн. ш., $36.953^{\circ}$ сх. д. (функціонує з 2013 р.) [11].

Метою цієї статті $€$ пошук і порівняння прояву семиденної циклічності в оптичних характеристиках аерозолів, зокрема АОТ, виміряної на довжинах хвиль 440 і 870 нм (АОТ440 та АОТ870), в регіонах України з різним рівнем техногенного навантаження. Оригінальність роботи полягає в тому, що раніше такі дослідження в м. Києві та рекреаційній зоні Харківської області, якою $€$ с. Мартове, не виконувалися. Такий аналіз надає можливість оцінити просторові масштаби поширення аерозольних забруднень від урбанізованих та промислово розвинутих регіонів.

\section{2. Методика спостережень}

У дослідженні використовувались результати вимірювань, отримані за допомогою сонячних фотометрів Cimel CE-318 всесвітньої мережі AERONET [12]. Ці прилади призначені для реєстрації розсіяного та прямого сонячного випромінювання на декількох довжинах хвиль у діапазоні від
340 до 1640 нм. Принципи роботи системи AERONET, методика вимірювань та обробки даних досить детально викладені у попередніх працях $[3,8]$. Для подальшого синхронного порівняльного аналізу було обрано українські станції AERONET Київ і Мартова. В мережі AERONET наведено дані декількох рівнів якості (http:// aeronet.gsfc.nasa.gov): Level 1 - первинні дані; Level 1.5 - дані, що пройшли первинну обробку з вилученням впливу хмарності. Значення АОТ рівня Level $2.0 €$ виправленими 3 урахуванням впливу хмарності та зміни характеристик сонячного фотометра між калібруваннями. Саме за значеннями рівня Level 2.0 було виконано пошук періодичності в вимірюваннях AOT.

Для вибору найбільш повного річного масиву даних було виконано статистичні оцінки кількості зареєстрованих аерозольних параметрів за весь проміжок одночасного моніторингу на станціях Київ та Мартова з 2013 до 2017 рр. Встановлено, що дані спостережень у 2014 р. виявилися статистично найповнішими для двопозиційного порівняння вмісту аерозолів.

На рис. 1 наведено кількість щомісячних вимірювань для років спільних спостережень на станціях Київ та Мартова (2014-2017рр.).

Згідно статистичної інформації, зібраної на території м. Києва [13], у 2014 р. загальна величина забруднюючих атмосферу речовин, у тому числі i аерозолів, складала 214.2 тис. т, 3 яких понад 180 тис. т надходили від пересувних джерел забруднення (тобто автотранспорту). В той час як кількість викидів забруднюючих речовин від стаціонарних та пересувних джерел всієї Харківської області загалом 3 промисловим м. Харковом та містами районного значення у 2014 р. склала 283 тис. т [14]. Печенізький район, в якому розташована станція Мартова (на території с. Мартове), є рекреаційною зоною, і його частка в загальному обсязі викидів забруднюючих атмосферу речовин у цьому регіоні $\epsilon$ незначною.

Для двохпозиційної порівняльної обробки даних вимірювань АОТ була використана вибірка спостережень 3 квітня по жовтень 2014 р. Виключення з розгляду зимового сезону пов'язане, по-перше, 3 невеликою кількістю сонячних днів $(5 \div 10$ днів на місяць). По-друге, на покази фотометра у с. Мартове в цей період суттєво впливають локальні забруднення викидами від пічного опалення. Отже, повний обсяг спостережень АОТ з квітня 


\section{Кількість днів}
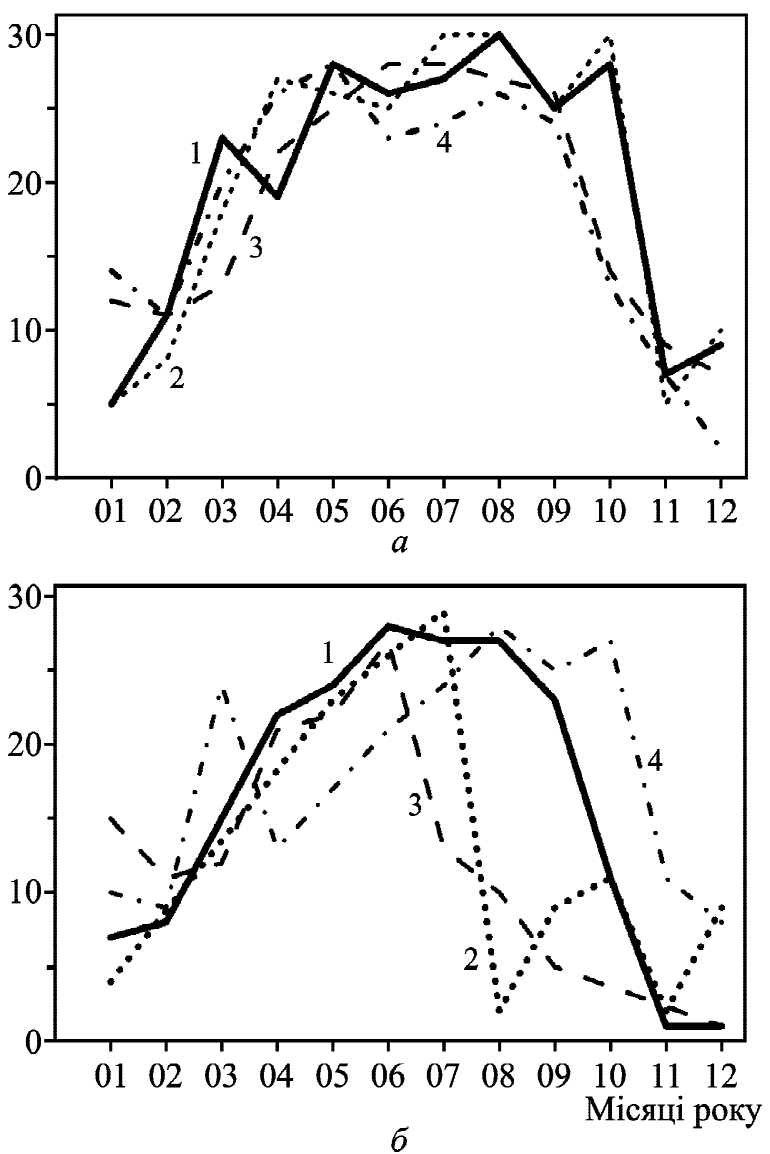

Puc. 1. Кількість днів успішних вимірювань сонячного фотометра у 2014-2017 pр. на станції Київ (a) та станції Мартова (б): крива 1 - 2014 р., крива 2 - 2015 р., крива 3 - 2016 р., крива $4-2017$ p.

по жовтень склав 183 дні на станції Київ і 155 днів на станції Мартова. Кількість днів одночасних двопозиційних вимірювань цього року була найвища і становила 141.

Для порівняльної статистичної обробки обрано метод накладання епох [15]. Він полягає в тому, що всі дані було розбито за днями тижня. Для кожної доби оцінювались середні значення АОТ440 та АОТ870, середньо квадратичні відхилення вказаних величин та стандартна похибка середнього. Після цього будувались тижневі залежності усереднених щоденних значень АОТ440 та AOT870.

\section{3. Результати спостережень}

Як зазначено вище, у якості інформаційних параметрів вмісту аерозольних частинок у повітрі обрано вимірювання АОТ на двох довжинах хвиль
870 та 440 нм: АОТ870 та АОТ440. Треба відзначити, що діапазон спектру поблизу довжини хвилі 870 нм на відміну від діапазона спектру поблизу 440 нм є вільним від молекулярного поглинання $\mathrm{NO}_{2}[16,17]$, тобто величина АОТ870 залежить виключно від вмісту в атмосфері аерозолів.

Умови розташування сонячного фотометра в Україні на двох станціях відрізняються. У с. Мартове сонячний фотометр встановлено в Низькочастотній обсерваторії Радіоастрономічного інституту НАН України на значній відстані від великих міст та промислових джерел забруднення довкілля (понад 50 км від м. Харкова, на березі Печенізького водосховища). Фотометр станції Київ розташовано на даху Головної астрономічної обсерваторії НАН України на відстані близько 10 км від центра міста.

Для оцінки річної поведінки вмісту аерозолів в атмосфері над обома станціями було розраховано середні значення АОТ440 та АОТ870 за однаковий період 3 квітня по жовтень впродовж чотирьох років спостережень (2014-2017рр.). Результати оцінювання наведені в табл. 1.

Згідно 3 даними таблиці, середнє значення АОТ870 за період від квітня до жовтня включно, виміряне на станції Мартова, $є$ вищим, ніж виміряне на станції Київ у всі роки спостережень, тоді як середні оцінки АОТ440 виявилися вищими лише у 2014 та 2017 pp.

Аналіз поведінки середньодобових варіацій АОТ440 у контрольний 2014 р. виконано для 141 доби двохпозиційних вимірювань. Він показав, що максимуми цієї величини спостерігаються у п'ятницю в обох пунктах, близькими виявилися і середні значення (див. рис. 2). Тижнева поведінка параметра АОТ440, виміряного на станціях Київ і Мартова, є подібною.

Таблиия 1. Середні значення АОТ440 та АОТ870 за даними станцій Київ та Мартова за період спостережень 3 квітня по жовтень включно (сім місяців)

\begin{tabular}{|c|c|c|c|c|}
\hline \multirow{2}{*}{ Роки } & \multicolumn{2}{|c|}{$\begin{array}{c}\text { Середнє значення } \\
\text { АОТ440 }\end{array}$} & \multicolumn{2}{c|}{$\begin{array}{c}\text { Середнє значення } \\
\text { АОТ870 }\end{array}$} \\
\cline { 2 - 5 } & Київ & Мартова & Київ & Мартова \\
\hline 2014 & 0.196 & 0.210 & 0.070 & 0.079 \\
2015 & 0.211 & 0.177 & 0.074 & 0.077 \\
2016 & 0.233 & 0.206 & 0.087 & 0.096 \\
2017 & 0.194 & 0.222 & 0.076 & 0.093 \\
\hline
\end{tabular}




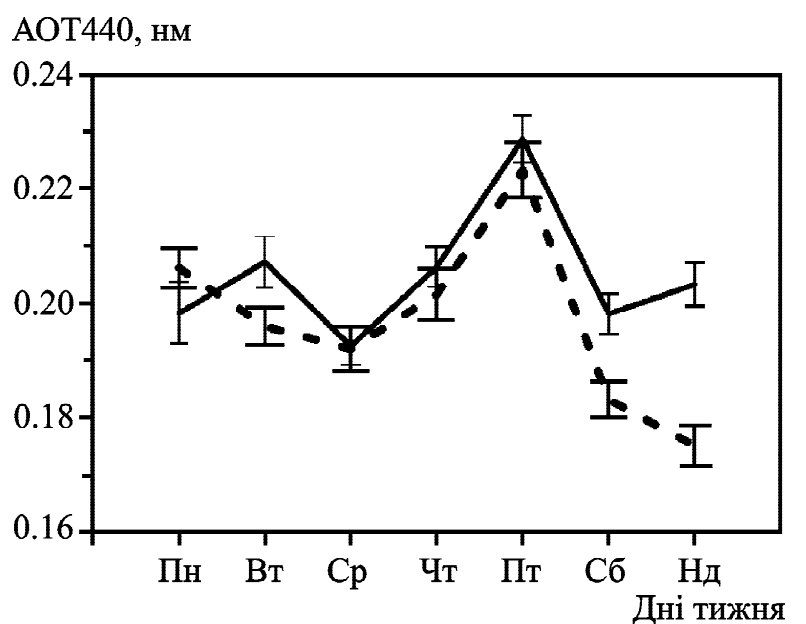

Puc. 2. Залежність АОТ440 від дня тижня за даними станцій AERONET Київ (пунктирна лінія) та Мартова (суцільна лінія) у 2014 р. (з квітня по жовтень)

Залежності АОТ, виміряної на довжині хвилі 870 нм на двох станціях у період спільних спостережень, від дня тижня наведено на рис. 3. Після обчислення і порівняння даних з'ясувалося, що тижневий цикл варіацій АОТ870 є практично ідентичним в обох пунктах. Максимальне значення тижневої варіації припадає на п'ятницю, мінімальне - на вихідні дні. Середні значення величини АОТ870 дещо відрізняються і складають для станції Київ - 0.07, а для станції Мартова -0.08 .

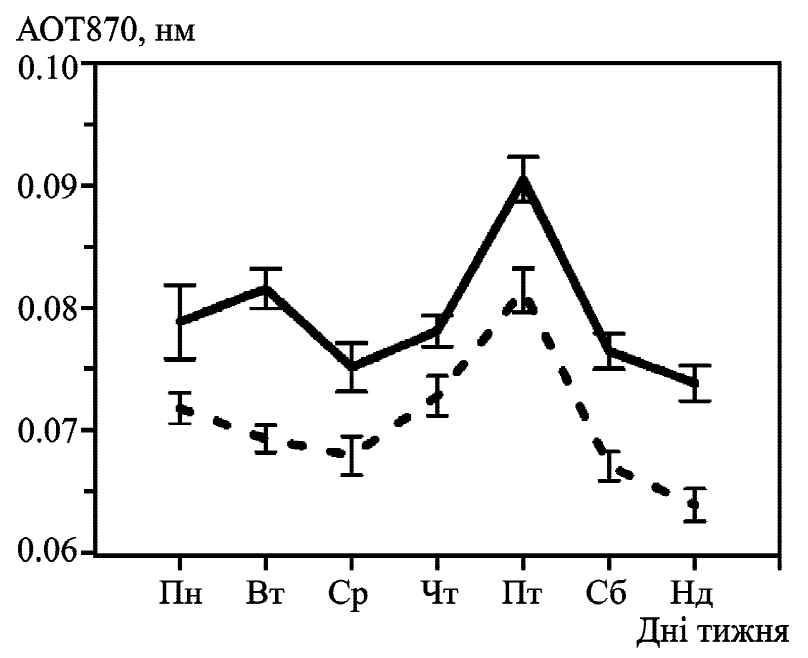

Puc. 3. Залежність АОТ870 від дня тижня за даними станцій AERONET Київ (пунктирна лінія) та Мартова (суцільна лінія) у 2014 р. (з квітня по жовтень)

\section{4. Обговорення результатів}

Спільний аналіз поведінки залежностей АОТ440 та АОТ870 від дня тижня на двох українських станціях мережі AERONET показав їх дуже схожий характер. Для перевірки подібності прояву “уікендефекту” у концентрації аерозолів в атмосфері м. Києва та с. Мартове було оцінено коефіцієнти взаємної кореляції рядів середніх значень параметрів АОТ440 і АОТ870, розрахованих за даними двох станцій. Встановлено, що максимальна кореляція варіацій АОТ на довжині хвилі 440 нм становить приблизно 0.7, а на довжині хвилі 870 нм сягає 0.9. Такі результати дозволяють стверджувати, що прояв “уікенд-ефекту” як у екологічно чистому регіоні (с. Мартове), так і в індустріально розвинутому м. Києві є практично ідентичним.

Це надає можливість припустити, що просторові масштаби техногенного впливу на атмосферні характеристики складають понад десятки кілометрів (відстань від індустріального центра м. Харкова до с. Мартове становить понад 50 км). Це припущення $€$ попереднім, надалі планується детальний аналіз особливостей прояву "уікендефекту” та вивчення фонових показників вмісту аерозолів над кожною станцією. Відзначимо, що аналогічні висновки були зроблені нами при досліджені проявів семиденної циклічності вмісту аерозолів в атмосфері у Свропі і Північній Америці $[3,8]$, де середні континентальні семиденні оцінки здійснювались за даними декількох просторово рознесених пунктів спостережень. Як і в попередніх дослідженнях, за даними європейських та американських пунктів моніторингу, максимум варіацій AOT на двох станціях AERONET в Україні спостерігається у п'ятницю.

Отримані результати щодо практично однакового характеру прояву “уікенд-ефекту” у суттєво різних за техногенним навантаженням рознесених пунктах спостережень (м. Київ і с. Мартове) виявилися досить неочікуваними. Передбачається у подальшому розширити масиви даних спільних вимірювань, а також долучити до обробки дані спостережень варіацій АОТ зі станцій AERONET, розташованих у сусідніх країнах (наприклад, у Польщі, Угорщині та Білорусі).

\section{5. Висновки}

В роботі за даними річних вимірювань на двох розташованих в Україні станціях мережі AERONET (Київ і Мартова) вперше виконано 
пошук проявів семиденної циклічності у поведінці варіацій АОТ на довжинах хвиль 440 та 870 нм.

Встановлено наявність “уікенд-ефекту" в поведінці середньодобових залежностей параметрів AOT440 та АОТ870 в обох пунктах. Тижневий максимум припадає на п'ятницю.

Для встановлення подібності поведінки тижневих варіацій АОТ на двох станціях розраховано коефіцієнти взаємної кореляції. Їх значення для AОТ440 і АОТ870 виявилися досить високими і склали відповідно 0.7 і 0.9.

Авторка вдячна науковому керівнику члену-кореспонденту НАН України Ю. М. Ямпольському за постановку задачі досліджень, а також доктору фіз.-мат. наук Г. П. Міліневському за організацію вимірювань атмосферних аерозолів в Україні і за плідні поради. Я також вдячна В. О. Данилевському за дозвіл використовувати дані станції Київ та колегам з відділу радіофізики геокосмосу РІ НАН України.

Дослідження виконано в рамках відомчої бюджетної НДР “Ятаган -3” (номер держреєстрації 016U000035) та частково фінансово підтримані в рамках конкурсної НДР “Шпіцберген-2018” (номер держреєстрації 0118U000562). Окремо дякую співробітникам міжнародної мережі AERONET за можливість виконувати дослідження за даними мережі.

\section{СПИСОК ЛІТЕРАТУРИ}

1. Cerveny R. S. and Coakley K. J. A weekly cycle in atmospheric carbon dioxide. Geophys. Res. Lett. 2002. Vol. 29, Is. 2. P. 15-1-15-4. DOI: 10.1029/2001GL013952

2. Sanchez-Lorenzo A., Laux P., Hendricks Franssen H.-J., Calbó J., Vogl S., Georgoulias A. K., and Quaas J. Assessing large-scale weekly cycles in meteorological variables: a review. Atmos. Chem. Phys. 2012. Vol. 12, Is. 13. P. 5755-5771. DOI: 10.5194/acp-12-5755-2012

3. Пазнухов А. В., Ямпольский Ю. М., Занимонский Е. М., Соина А. В. Поиск "уикенд эффекта" в вариациях интенсивности природных СНЧ шумов. Радиофизика и радиоастрономия. 2012. Т. 17, № 1. С. 67-73. URL: http://rpra-journal.org.ua/index.php/ra/article/view/414/308 (дата обращения: 4.04.2019).

4. Seinfeld J. H. and Pandis S. N. Atmospheric chemistry and physics: from air pollution to climate change. Third edition. Hoboken, New Jersey, US: John Wiley \& Sons, Inc., 2016. $1121 \mathrm{p}$.

5. Чекман И. С., Сыровая А. О., Андреева С. В., Макаров В. А. Аэрозоли - дисперсные системы: Моно- графия. Харьков: Цифрова друкарня № 1, 2013. $100 \mathrm{c}$.

6. Bäumer D., Rinke R., and Vogel B. Weekly periodicities of Aerosol Optical Thickness over Central Europe - evidence of an anthropogenic direct aerosol effect. Atmos. Chem. Phys. 2008. Vol. 8, Is. 1. P. 83-90. DOI: 10.5194/ acp-8-83-2008

7. Holben B. N., Eck T. F., Slutsker I., Tanré D., Buis J. P., Setzer A., Vermote E., Reagan J. A., Kaufman Y. J., Nakajima T., Lavenu F., Jankowiak I., and Smirnov A. AERONET - A Federated Instrument Network and Data Archive for Aerosol Characterization. Remote Sens. Environ. 1998. Vol. 66, Is. 1. P. 1-16. DOI: 10.1016/S0034-4257(98)00031-5

8. Соина А. В., Милиневский Г. П., Ямпольский Ю. М. Семидневные вариации в атмосферных аэрозолях. Радиофизика и радиоастрономия. 2015. Т. 20, № 2 . C. 109-121. DOI: 10.15407/rpra20.02.109

9. Галицька Є. І., Данилевський В. О., Сніжко С. І. Стан забруднення аерозолем атмосфери над Києвом за дистанційними дослідженнями засобами AERONET та вплив на нього лісових пожеж улітку 2010 р. Геополитика и экогеодинамика регионов. 2014. Т. 10. С. 437-444.

10. Bovchaliuk A., Milinevsky G., Danylevsky V., Goloub P., Dubovik O., Holdak A., Ducos F., and Sosonkin M. Variability of aerosol properties over Eastern Europe observed from ground and satellites in the period from 2003 to 2011. Atmos. Chem. Phys. 2013. Vol. 13, Is. 13. P. 6587-6602. DOI: 10.5194/acp-13-6587-2013

11. Milinevsky G. and Danylevsky V. Atmospheric Aerosol Over Ukraine Region: Current Status of Knowledge and Research Efforts. Front. Environ. Sci. 2018. Vol. 6. id 59. DOI: $10.3389 /$ fenvs.2018.00059

12. Андерсон Т. Статистический анализ временных рядов. Пер. с англ. Москва: Мир, 1976. 755 с.

13. Головне управління статистики у місті Києві. Викиди забруднюючих речовин та діоксиду вуглецю у атмосферне повітря (1990-2017 роки). 2019. URL: http:// kiev.ukrstat.gov.ua/p.php3?c=1730\&lang=1 (дата обращения: 4.04.2019).

14. Головне управління статистики в Харківській області. Викиди забруднюючих речовин та діоксиду вуглецю в атмосферне повітря (1990-2017 рр.). 2019. URL: http://kh.ukrstat.gov.ua/index.php/dynamika-vykydivzabrudniuiuchykh-rechovyn-i-dioksydu-vuhletsiu-vatmosferne-povitria (дата обращения: 4.04.2019).

15. Серебренников М. Г., Первозванский А. А. Вылявление скрытых периодичностей. Москва: Наука, 1965. 244 с.

16. Burrows J. P., Dehn A., Deters B., Himmelmann S., Richter A., Voigt S., and Orphal J. Atmospheric remote-sensing reference data from GOME: Part 1. Temperature-dependent absorption cross-sections of NO2 in the 231-794 nm range. J. Quant. Spectrosc. Radiat. Transf. 1998. Vol. 60, Is. 6. P. 1025-1031. DOI: 10.1016/S0022-4073(97)00197-0

17. Milinevsky G., Danylevsky V., Bovchaliuk V., Bovchaliuk A., Goloub Ph., Dubovik O., Kabashnikov V., Chaikovsky A., Miatselskaya N., Mishchenko M., and Sosonkin M. Aerosol seasonal variations over urban-industrial regions in Ukraine according to AERONET and POLDER measurements. Atmos. Meas. Tech. 2014. Vol. 7, Is. 5. P. 1459-1474. DOI:10.5194/amt-7-1459-2014 


\section{REFERENCES}

1. CERVENY, R. S. and COAKLEY, K. J., 2002. A weekly cycle in atmospheric carbon dioxide. Geophys. Res. Lett. vol. 29 , is. 2 , pp. 15-1-15-4. DOI: 10.1029/2001GL013952

2. ANCHEZ-LORENZO, A., LAUX, P., HENDRICKS FRANSSEN, H. -J., CALBÓ, J., VOGL, S., GEORGOULIAS, A. K. and QUAAS, J., 2012. Assessing large-scale weekly cycles in meteorological variables: a review. Atmos. Chem. Phys. vol. 12, is. 13, pp. 5755-5771. DOI: $10.5194 /$ acp-12-5755-2012,

3. PAZNUKHOV, A. V., YAMPOLSKI, Y. M., ZANIMONSKIY, Y. M. and SOINA, A. V., 2012. Search of "weekend effect" in the intensity of natural VLF noise variations. Radio Phys. Radio. Astron. [online]. vol. 17, no. 1, pp. 67-73. (in Russian). [viewed 4 April 2019]. Available from: http://rpra-journal.org.ua/index.php/ra/article/view/ 414/308

4. SEINFELD, J. H. and PANDIS, S. N., 2016. Atmospheric chemistry and physics: from air pollution to climate change. Third edition. Hoboken, New Jersey, US: John Wiley \& Sons, Inc.

5. CHEKMAN, E. S., SYROVAYA, A. O., ANDREEVA, S. V. and MAKAROV, V. A., 2013. Aerosols - disperse systems: Monograph. Kharkiv, Ukraine: Tsyfrova drukarnya no. 1 Publ. (in Russian).

6. BÄUMER, D., RINKE, R. and VOGEL, B., 2008. Weekly periodicities of Aerosol Optical Thickness over Central Europe - evidence of an anthropogenic direct aerosol effect. Atmos. Chem. Phys. vol. 8, is. 1, pp. 83-90. DOI: 10.5194/acp-8-83-2008

7. HOLBEN, B. N., ECK, T. F., SLUTSKER, I., TANRÉ, D., BUIS, J. P., SETZER, A., VERMOTE, E., REAGAN, J. A., KAUFMAN, Y. J., NAKAJIMA, T., LAVENU, F., JANKOWIAK, I. and SMIRNOV, A., 1998. AERONET - A Federated Instrument Network and Data Archive for Aerosol Characterization. Remote Sens. Environ. vol. 66, is. 1, pp. 1-16. DOI: 10.1016/S00344257(98)00031-5

8. SOINA, A. V., MILINEVSKY, G. P. and YAMPOLSKI, Y. M., 2015. Seven-day variations in the atmospheric aerosols. Radio Phys. Radio. Astron. vol. 20, no. 2, pp. 109-121. (in Russian). DOI: 10.15407/rpra20.02.109

9. GALITSKA, E. I., DANYLEVSKY, V. O. and SNIZHKO, S. I., 2014. State of aerosol pollution of the atmosphere over Kyiv by means of remote studies AERONET and the impact of forest fires in summer of 2010. Geopolitika i ekogeodinamika regionov. vol. 10, pp. 437-444. (in Ukrainian).

10. BOVCHALIUK, A., MILINEVSKY, G., DANYLEVSKY, V., GOLOUB, P., DUBOVIK, O., HOLDAK, A., DUCOS, F. and SOSONKIN, M., 2013. Variability of aerosol properties over Eastern Europe observed from ground and satellites in the period from 2003 to 2011. Atmos. Chem. Phys. vol. 13, is. 13, pp. 587-6602. DOI: 10.5194/ acp-13-6587-2013

11. MILINEVSKY, G. and DANYLEVSKY, V., 2018. Atmospheric Aerosol Over Ukraine Region: Current Status of Knowledge and Research Efforts. Front. Environ. Sci. vol. 6, id 59. DOI: 10.3389/fenvs.2018.00059
12. ANDERSON, T., 1971. The Statistical Analysis of Time Series. New York: John Wiley \& Sons, Inc.

13. THE MAIN DEPARTMENT OF STATISTICS IN KIEV CITY, 2019. Emissions of pollutants and carbon dioxide into the atmosphere (1990-2017) [online]. (in Ukrainian). [viewed 4 April 2019]. Available from: http://kiev. ukrstat.gov.ua/p.php3?c=1730\&lang $=1$

14. THE MAIN DEPARTMENT OF STATISTICS IN THE KHARKIV REGION. Emissions of pollutants and carbon dioxide into the atmosphere (1990-2017) [online]. (in Ukrainian). [viewed 4 April 2019]. Available from: http://kh.ukrstat.gov.ua/index.php/dynamika-vykydivzabrudniuiuchykh-rechovyn-i-dioksydu-vuhletsiu-vatmosferne-povitria

15. SEREBRENNIKOV, M. G. and PERVOZVANSKY, A. A., 1965. Detection of the hidden periodicities. Moskow, Russia: Nauka Publ. (in Russian).

16. BURROWS, J. P., DEHN, A., DETERS, B., HIMMELMANN, S., RICHTER, A., VOIGT, S. and ORPHAL, J., 1998. Atmospheric remote-sensing reference data from GOME: Part 1. Temperature-dependent absorption crosssections of $\mathrm{NO}_{2}$ in the 231-794 nm range, J. Quant. Spectrosc. Radiat. Transf. vol. 60, is. 6, pp. 1025-1031. DOI: 10.1016/S0022-4073(97)00197-0

17. MILINEVSKY, G., DANYLEVSKY, V., BOVCHALIUK, V., BOVCHALIUK, A., GOLOUB, PH., DUBOVIK, O., KABASHNIKOV, V., CHAIKOVSKY, A., MIATSELSKAYA, N., MISHCHENKO, M. and SOSONKIN, M., 2014. Aerosol seasonal variations over urban-industrial regions in Ukraine according to AERONET and POLDER measurements. Atmos. Meas. Tech. vol. 7, is. 5, pp. 1459-1474. DOI: $10.5194 / \mathrm{amt}-7-1459-2014$

\section{A. V. Soina}

Institute of Radio Astronomy,

National Academy of Sciences of Ukraine,

4, Mystetstv St., Kharkiv, 61002, Ukraine

\section{SEVEN-DAY CYCLE IN THE PARAMETERS OF ATMOSPHERIC AEROSOLS ACCORDING TO THE UKRAINIAN AERONET STATIONS DATA}

Purpose: The work is aimed at searching, analyzing and comparison of weekly cycles in the behavior of optical characteristics of atmospheric aerosols, namely, the aerosol optical thickness in the regions of Ukraine with different degrees of anthropogenic load on the environment.

Design/methodology/approach: To search for the seven-day variations, the data were used from the worldwide aerosol monitoring network AERONET, whose activity is based on the Cimel CE-318 automated unified solar photometer robot (France). An array of annual measurements of the aerosol optical thickness in the two spectral channels -440 and $870 \mathrm{~nm}$ (hereinafter AOT440 and AOT870), in 2014 was analyzed. The monitoring data of two Ukrainian stations were compared. The first is located in Kyiv, the second - in the village of Martove, Pechenihy district, Kharkiv region. Since the data of the solar photometer are discrete, the method of superposing epochs was chosen for their statistical processing. 
Findings: As a result of calculations of the AOT440 and AOT870 parameters, the presence of seven-day variations in these parameters in both regions was established. In order to verify the similarity of the "weekend effect" in variations in the concentration of aerosols in the atmosphere over the city of Kyiv and the village of Martove, the maximum values of the mutual correlation coefficients of the parameters under study were determined. It is established that the correlation coefficient for the two series of the AOT440 parameter average values, calculated according to the two stations data, is approximately 0.7 , and of the AOT870 reaches 0.9 . These results suggest that the manifestations of the "weekend effect" in variations in the concentration of aerosols both over an ecologically clean area (Martove village) and over the industrially developed city of Kyiv are almost identical.

Conclusions: The presence of seven-day variations in the parameters of atmospheric aerosols AOT440 and AOT870 at two observation points in Ukraine has been established, the maximum average values of the parameters recorded are observed on Friday. The analysis showed the high degree of correlation of the results of observations at two stations. Given the varying degree of anthropogenic load of the urbanized region and the recreational zone of Ukraine in which the stations are located, and the high similarity of the seven-day cycles of the parameters AOT440 and AOT870 recorded in 2014, it can be argued that the previous studies findings on the global nature of human influence on the environment were confirmed.

Key words: aerosol optical thickness (AOT), aerosols, "weekend effect", atmosphere, cross-correlation, anthropogenic impact

\section{A. В. Соина}

Радиоастрономический институт НАН Украины, ул. Мыстэцтв, 4, г. Харьков, 61002, Украина

\section{СЕМИДНЕВНАЯ ЦИКЛИЧНОСТЬ В ПАРАМЕТРАХ АТМОСФЕРНЫХ АЭРОЗОЛЕЙ ПО ДАННЫМ СТАНЦИЙ AERONET В УКРАИНЕ}

Предмет и цель работь:: Целью работы является поиск, анализ и сравнение недельной цикличности в поведении оптических характеристик атмосферных аэрозолей, а именно аэрозольной оптической толщи, в регионах Украины с разной степенью техногенной нагрузки на окружающую среду. Методы и методология: Для поиска семидневных вариаций использовались данные всемирной сети мониторинга аэрозолей AERONET, деятельность которой основана на роботе автоматических унифицированных солнечных фотометров Cimel CE-318 (Франция). Был проанализирован массив годовых данных измерений аэрозольной оптической толщи в двух спектральных каналах - 440 и 870 нм, (далее АОТ440 и АОТ870) в 2014 г. Сравнивались данные мониторинга двух украинских станций. Первая находится в г. Киеве, вторая - в с. Мартовое Печенежского района Харьковской области. Поскольку данные солнечного фотометра являются дискретными, для их статистической обработки был выбран метод наложения эпох.

Результаты: В результате проведенных расчетов параметров АОТ440 и АОТ870 было установлено наличие семидневных вариаций в этих параметрах в обоих регионах. С целью проверки схожести “уикенд-эффекта” в вариациях концентрации аэрозолей в атмосфере над г. Киевом и с. Мартовое были определены максимальные значения коэффициентов взаимной корреляции исследуемых параметров. Установлено, что коэффициент корреляции для двух рядов средних значений параметра АОТ440, рассчитанных по данным двух станций, составляет примерно 0.7, а для АОТ870 достигает 0.9. Такие результаты позволяют утверждать, что проявления “уикенд-эффекта" в вариациях концентрации аэрозолей как над экологически чистой территорией (c. Мартовое), так и над индустриально развитым г. Киевом практически идентичны.

Заключение: Установлено наличие семидневных вариаций в параметрах атмосферных аэрозолей АОТ440 и АОТ870 в двух пунктах наблюдений в Украине, максимальные значения параметров регистрируются в пятницу. Анализ показал высокую степень корреляции результатов наблюдений на двух станциях. Учитывая разную степень антропогенной нагрузки на урбанизированный район и рекреационную зону Украины, в которых расположены станции, и высокую схожесть семидневных циклов параметров АОТ440 и АОТ870, зарегистрированных в 2014 г., можно утверждать, что выводы предыдущих исследований относительно важности и глобальности влияния человека на окружающую среду подтвердились.

Ключевые слова: аэрозольная оптическая толща (АОТ), аэрозоли, “уикенд-эффект”, атмосфера, взаимная корреляция, антропогенное влияние

Стаття надійшла до редакиії 04.04.2019 